\title{
シクロプロパン環を含むビシクロ型ラクトン, ウレタン,
} およびそれらに対応するトランス異性体の合成*1

(昭 和 41 年 2 月 24 日 受理)

\author{
庄野達哉・鳴井＼cjkstart衛・奥＼cjkstart彬・小田良平*2
}

\begin{abstract}
シス-1,2-シクロプロパンジカルボン酸塩化物をソジゥムボロハイドライドで還元して，2-ケト，3-オキサビシクロ [3.1.0] キサン［］］を合成した。しかし，この還元に拈いては，1,2-ジメチロールシクロプロパンが副生した。。次にシスー1,2-シクロプ ロパンジカルボン酸モノメチルエステル，モノ酸塩化物を同樣に還元して［I］を良い収率で得た。［I］は重合性を示さないが， これは 5 員環ラクトンの一般的性質である。またこのラクトン［I］を，ヒドラジンヒドラートで処理して得られるヒドラジドか

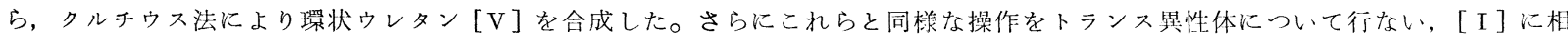

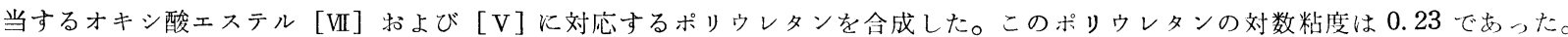
また [VI] から得られたポリエステルの対数粘度は 0.14 であった。
\end{abstract}

シクロプロパン誘導体に抒いて，その 1 扎よび 2 位置に同じ置 換基を持つもの (対称型) は, 既報1)のようにシスおよびトラン ス異性体のいずれに打いても比較的容易に 1,2 -ジカルボン酸か ら合成することができるが，二つの置換基が異なる場合（非対称 型）には合成は容易ではない。しかし，ある種の二塩基酸におい て，その酸塩化物あるいはモノェステルを，ソジウムボロハイド ライドで還元すると,ラクトンを与えることが認められている2)。

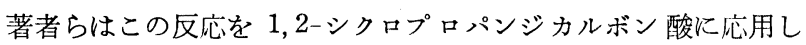
てシス異性体からラクトン（1），トランス異性体からオ非酸 エステル（UI）を合成し，これらを出発物質としてさらに若干の 非対称型誘導体を合成した。

I は 2 種類の方法により合成した。すなわち第一の方法は（1） 式に示すよ5に, 対応する酸塩化物の還元による一段階ラクトン 化である。

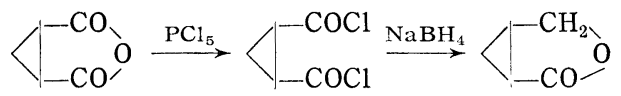

この方法に括いては，一方の置換基の還元で生成したメチロー ル基と残った塩化アシル基との反応で, ラクトン化が起こる訳で あるが，収率は良好でなく，常にさらに還元の進んだジメチロー ル誘導体を多量生成した。これは還元が必ずしも段階的に進んで いないことを示している。結果は表 1 亿示す。この結果によれば 溶媒としてはテトラヒドロフランが最も適当と思われるが, しか

\begin{tabular}{|c|c|c|c|c|c|c|}
\hline \multirow[b]{2}{*}{ 番号 } & \multicolumn{4}{|c|}{ 表 } & \multirow[b]{2}{*}{$\begin{array}{l}\text { 時間 } \\
(\mathrm{hr})\end{array}$} & \multirow[b]{2}{*}{$\begin{array}{l}\text { 収率 } \\
(\%)\end{array}$} \\
\hline & $\underset{\text { /酸塭化物 }}{\mathrm{NaBH}_{4}}$ & 溶 & 媒 & $\begin{array}{l}\text { 温度 } \\
\text { (C) }\end{array}$ & & \\
\hline 1 & 1 & \multicolumn{2}{|c|}{ テトラヒドロフラン } & 67 & 3.5 & 3.1 \\
\hline 2 & 2 & \multicolumn{2}{|c|}{ " } & $"$ & 6 & 18.4 \\
\hline 3 & 2 & \multicolumn{2}{|c|}{ " } & " & 10 & 8.5 \\
\hline 4 & 2 & \multicolumn{2}{|c|}{ " } & " & 24 & 10.4 \\
\hline 5 & 1 & \multicolumn{2}{|c|}{$\begin{array}{l}\text { ジェチングリコール } \\
\text { ジメチルェーテル }\end{array}$} & 100 & 2 & 6.1 \\
\hline 6 & 2 & \multicolumn{2}{|c|}{ ジオキサン } & 60 & 3 & 0 \\
\hline 7 & 2 & \multicolumn{2}{|c|}{ " } & 100 & 24 & 7.7 \\
\hline
\end{tabular}

*1 本研究を「小員環化合物（第 10 報）」とする; 前報（第 9 報), 奥 樹, 庄野達哉, 小田良平, Makromol. Chem. 投稿中.

*2 Tatsuya Shono, Mamoru NARUI, Akira OKU, Ryohei ODA 京都大学工学部合成化学科: 京都市左京区吉田.

1) T. Shono, T. Morikawa, R. Okayama, R. Oda, Makromol. Chem., 81, 142 (1965).

2) S. W.Choikin, W. G. Brown, J. Am. Chem. Soc., 71, 122 (1949).
し還元条件と収率の関係を検討するには収率が十分でなく, むし ろ還元剤の品質が最も大きな因子であると思われる。

一方，第二の方法は（2）式に示すように，モノェステルを経 由する方法である。

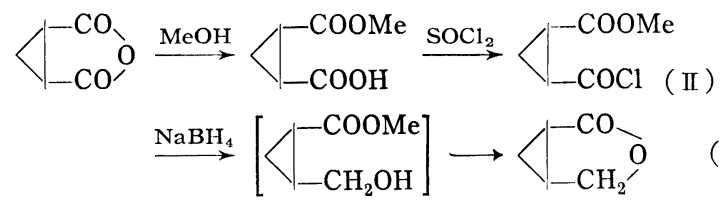

この方法に括いては，恐らく中間に生成するオキシ酸エステル の分子内エステル交換によりラクトン化が進さと考觉られるが， 一般にカルボン酸エステルは, 通常の条件ではりジウムボロハイ ドライドによってアルコールにまで還元されないので, ジメチロ ール誘導体を副生することなくかなり良い収率でラクトン（I）を 得ることができた。結果は表 2 亿示す。この結果は, 還元剤の品 質が一定でないために，反灾条件を吟味するのに必ずしも十分で はないが，溶媒としてテトラヒドロフランを用い，還元剂と（II） のモル比, $1 \sim 2$, 反応温度はテトラヒドロフランの沸点, そして 反応時間 $0.5 \sim 1$ 時間のような条件が最適と思われる。

\begin{tabular}{|c|c|c|c|c|c|c|}
\hline 番号 & $\mathrm{NaBH}_{4} /$ (II) & 溶 & 媒 & $\begin{array}{l}\text { 温度 } \\
\left({ }^{\circ} \mathrm{C}\right)\end{array}$ & $\begin{array}{l}\text { 時間 } \\
(\mathrm{hr})\end{array}$ & $\begin{array}{l}\text { 収率 } \\
(\%)\end{array}$ \\
\hline 1 & 0.5 & \multicolumn{2}{|c|}{ テトラヒドロフラン } & 67 & 1 & 10.6 \\
\hline 2 & $" \prime$ & \multicolumn{2}{|c|}{ " } & 11 & 5 & 7.2 \\
\hline 3 & 1 & \multicolumn{2}{|c|}{$" 1$} & $" 1$ & 0.5 & 21.1 \\
\hline 4 & 1 & \multicolumn{2}{|c|}{ " } & 30 & 1 & 34.8 \\
\hline 5 & 1.5 & \multicolumn{2}{|c|}{$" \prime$} & 67 & 0.5 & 51.8 \\
\hline 6 & $" 1$ & \multicolumn{2}{|c|}{ " } & 30,60 & 1,1 & 43.6 \\
\hline 7 & $" 1$ & \multicolumn{2}{|c|}{$" \prime$} & 30 & 3 & 33.4 \\
\hline 8 & 2 & \multicolumn{2}{|c|}{ " } & 67 & 0.5 & 54.7 \\
\hline 9 & 4 & \multicolumn{2}{|c|}{ " } & $" 1$ & $" 1$ & 23.1 \\
\hline 10 & 2 & \multicolumn{2}{|c|}{ ジオキサン } & 90 & $1 "$ & 0 \\
\hline 11 & "1 & \multicolumn{2}{|c|}{$x ー テ ル$} & 30 & $1 "$ & 0 \\
\hline
\end{tabular}

一般に 5 員環ラクトンは開環重合の困難なことが知られている が（I）も予期されたよ5に，ラクトンの開環重合条件で全く安 定であった。またブチロラクトンはトリエチルアルミニウムー水 系の触媒を使用してプロピオラクトンと共重合するが3)，（Ｉ）は この条件に括いても安定であった。（I）の配置がシス型に固定 されていることがこの様な安定化の一つの原因となっていると思

3) K. Tada, Y.Numata, T. Saegusa, J. Furukawa, Mak. romol. Chem., 77, 220 (1964). 
われる。

次に（I）から（３）式に示すよに環状ウレタンを合成した。

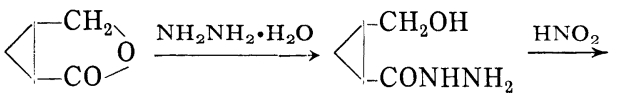

( I )

(III)

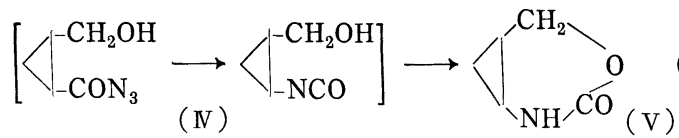

（Ｉ）とヒドラジンとの反応拈よびクルチウス転移は常法に従 って行なった。中間生成物である酸アジド，およびイソシアナー ト（N) を単離することは全く試みていないが，しかしクルチウ ス転移に持ける窒素発生が 完全に終了したのちも溶液中に（N） がかなり長時間存在することが IR スペクトルから認められ，ま た表 3 に示すよ5に, ウレタン（V）生成に比較的長時間の加熱 を必要とすることから，この（N） は構造から予期されるよりは 安定であると思われる。

\begin{tabular}{|c|c|c|c|c|c|}
\hline \multirow[b]{2}{*}{ 番号 } & \multicolumn{2}{|c|}{ 婊 } & \multicolumn{2}{|l|}{3} & \multirow[b]{2}{*}{ 収率 (\%) } \\
\hline & 時間 (hr) & 温度 $\left({ }^{\circ} \mathrm{C}\right)$ & 溶 & 媒 & \\
\hline 1 & 1 & 110 & & エン & 6.7 \\
\hline 2 & 5 & 110 & & & 30.2 \\
\hline 3 & 5 & 150 & $\gamma=$ & $-ル$ & 30.3 \\
\hline
\end{tabular}

次にトランス 1,2-シクロプロパンジカルボン酸を出発点とし て，(4) 式に示すような反応過程を経て, オキシ酸エステル（VI） およびイソシアナート（X）を合成した。

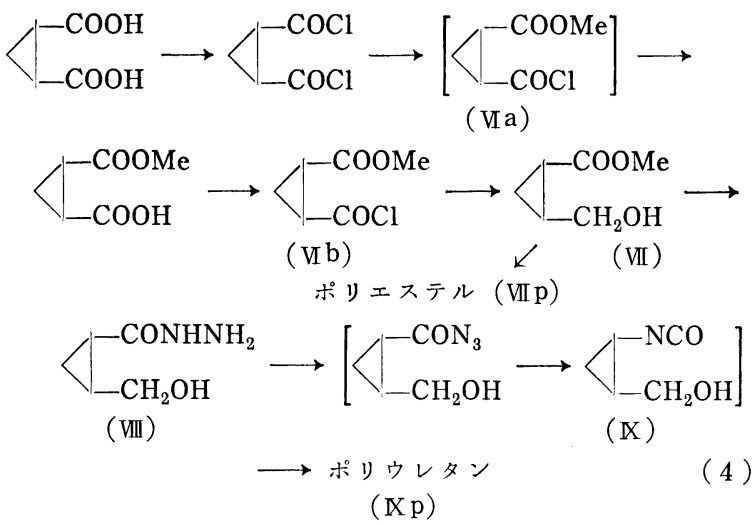

酸塩化物とメタノールとの反応で得られる（Va）はジェステ ルおよび末反応の酸塩化物を相当量混有しており，これらは蒸溜 による分離が困難である。従っていったんモノェステルカルボン 酸を単離することが不可欠であった。（Vb）から（VI）への睘元 はソジウムボロハイドライドを用い, シス異性体と類似の方法で 行なった。結果は表 4 に示す。

表 4

\begin{tabular}{|c|c|c|c|c|c|c|}
\hline 番号 & $\mathrm{NaBH}_{4} / \mathrm{VIb}$ & 溶 & 媒 & $\begin{array}{l}\text { 温度 } \\
\left({ }^{\circ} C\right)\end{array}$ & $\begin{array}{l}\text { 時間 } \\
(\mathrm{hr})\end{array}$ & $\begin{array}{l}\text { 収率 } \\
(\%)\end{array}$ \\
\hline 1 & 1 & テトラヒ & ドロフラン & 30 & 1 & 7 \\
\hline 2 & 1.5 & & $" 1$ & 67 & 5 & 22.6 \\
\hline 3 & 2 & & " & " & 1 & 35 \\
\hline 4 & 2 & & " & " & 2 & 32 \\
\hline 5 & 4 & & " & " & 1 & 63 \\
\hline
\end{tabular}

この結果から見れば還元は約 1 時間程度で終り，また還元剤は 過剩に存在する程良い結果を与えるようである。

Uは適当な条件で処理すればェステル交換によりポリェステル を与える。すなわち述を封管中, 触媒（三酸化アンチモンと酢酸

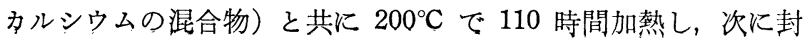

管内容物を減圧下 150 ～ $200^{\circ} \mathrm{C} て ゙ ~ 60$ 時間加熱すると粘稠なポリエ ステルを与古る。 $\eta_{\mathrm{inh}}=0.14$ (温度 $32^{\circ} \mathrm{C}$, 濃度 $0.5 \mathrm{~g} / 100 \mathrm{ml}$, 溶媒 $N, N$-ジメチルホルムアミド)。

次に（VI）から（X）を常法に従って合成した。（X）を単離 することは困難であるが，クルチウス転移の溶媒としてアニソー ルを用い，溶液をそのまま， $150^{\circ} \mathrm{C}$ で 5 時間加熱するとポリウレ タンを与える。 $\eta_{\mathrm{inh}}=0.23$ (温度 $32^{\circ} \mathrm{C}$, 濃度 $0.5 \mathrm{~g} / 100 \mathrm{ml}$, 溶 媒, $N, N$-ジメチルホルムアミド)。

ここに得られたポリエステル（MI p) は，先に著者らが合成し たトランス，1,2-シクロプロパンジカルボニルクロリドとトラン ス，1,2-ジメチロールシクロプロパンとからのポリエステル4) よ り良い性質を示した。しかし，一方，ポリウレタンはトランス， 1,2-シクロプロ パンジイソシアナートとトランス, 1,2-ジメチロ ールシクロプロパンとからのポリウレタン1)に比較して，その重 合度, 性質とも著しく劣る。これは単量体（X) の純度が必ずし も良くないことが最も大きな理由と思われる。

\section{実 験 の 部}

\section{ラクトン（I）の合成}

(A) 法 シス-1,2-シクロプロパンジカルボン酸クロリド 10.9 $\mathrm{g}(0.07 \mathrm{~mol})$ と $20 \mathrm{ml}$ のテトラヒドロフランの混合溶液を, 50 $\mathrm{m} l$ のテトラヒドロフランに $5 \mathrm{~g}(0.13 \mathrm{~mol})$ のソジウムボロハ イドライドを懸濁させた混合物中に温度 $0^{\circ} \mathrm{C}$ で滴下し, 滴下後 6 時間還流者沸した。次にこの反応混合物を $0^{\circ} \mathrm{C}$ に冷却し，未反応 の還元剤を分解するために $10 \mathrm{ml}$ の水を徐々に加光, 口過し, 無水硫酸マグネシウムで乾燥後，分別蒸留して $1.2 \mathrm{~g}(18.4 \%)$ のラクトン ( I ) を得た。bp $85 \sim 86^{\circ} \mathrm{C} / 7 \mathrm{mmHg}$ 。分析值 (理論 值, $\mathrm{C}_{5} \mathrm{H}_{6} \mathrm{O}_{2}$ として) C $61.22 \%(61.21 \%) ; \mathrm{H} 6.51 \%(6.17 \%) 。$

(B) 法 酸無水物 $112 \mathrm{~g}(1 \mathrm{~mol})$ と無水メチルアルコール 39 $\mathrm{g}(1.2 \mathrm{~mol})$ の混合物を $30^{\circ} \mathrm{C}$ で, 1 時間反応させてジカルボン 酸のモノメチルエステルをほぼ定量的な収率で得た。 $\mathrm{mp} 46$ ～ $47^{\circ} \mathrm{C}$, bp $132 \sim 135^{\circ} \mathrm{C} / 45 \mathrm{mmHg}$ 。分析値 (理論值, $\mathrm{C}_{6} \mathrm{H}_{8} \mathrm{O}_{4}$ とし て) C $50.03 \%(50.00 \%)$; H 5.83\% (5.60\%)。

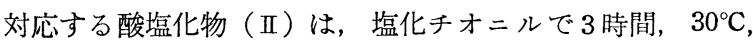
モノェステルを処理して得られた。 bp $100^{\circ} \mathrm{C} / 25 \mathrm{mmHg}$ (II) の （I）への還元は（A法）と同様に行なった。最高収率 $54.7 \%$ 。

\section{環状ウレタン（V）の合成}

ラクトン ( I ) $9.8 \mathrm{~g}(0.1 \mathrm{~mol})$ と $80 \%$ ヒドラジンヒドラー ト $7.5 \mathrm{~g}(0.12 \mathrm{~mol})$ との混合物を， $80^{\circ} \mathrm{C}$ で 1 時間加熱したのち 冷却して, 析出した結晶を口過, エチルアルコールから再結晶し

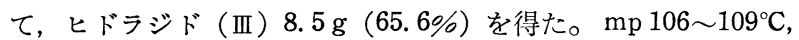
分析值 (理論值, $\mathrm{C}_{5} \mathrm{H}_{10} \mathrm{~N}_{2} \mathrm{O}_{2}$ として) C $46.09 \%$ (46.14\%); H $7.87 \%(7.75 \%) ; \mathrm{N} 21.64 \%(21.53 \%)$ 。

次に $13 \mathrm{~g}(0.1 \mathrm{~mol})$ の（III）を $70 \mathrm{ml}$ の水に溶解し, $10^{\circ} \mathrm{C}$ 以下で $10 \mathrm{~g}(0.11 \mathrm{~mol})$ の濃塩酸を加え, 次いで $60 \mathrm{ml}$ のトル エンを加えたのち, $0^{\circ} \mathrm{C}$ に冷却し,ささらに, $8.3 \mathrm{~g}(0.12 \mathrm{~mol})$ の 亜硝酸ナトリウムを $20 \mathrm{~m} l$ の水に溶解した溶液を $0^{\circ} \mathrm{C}$ 以下で滴 下した。反応混合物から有機層を分離し，別に水層をトルエンで 数回抽出して，これを先の有機層と合わせ， $0^{\circ} \mathrm{C}$ に保ちつつ無水 硫酸マグネシウムで乾燥した。次にこの溶液を $110^{\circ} \mathrm{C} に$ 加熱し,

4) R. Oda, T.Shono, A. Oku, H. Takao, Makromol. Chem., 67, 124 (1963). 
窒素の発生の終了後, さらに数時間 $110^{\circ} \mathrm{C}$ で加熱したのちトルェ ンを留去し, ウレタン（V) $3.4 \mathrm{~g}(30.2 \%)$ を得た。（V) はエー テルから再結晶して, mp $89 \sim 90^{\circ} \mathrm{C}$, 分析值 (理論值, $\mathrm{C}_{5} \mathrm{H}_{7} \mathrm{O}_{2} \mathrm{~N}$ そして) C 53.20\% (53.09\%); H 6.52\% (6.24\%); N 12.28\% $(12.38 \%)$ 。

\section{オキシ酸エステル（VII）の合成}

メチルアルコール $32 \mathrm{~g}(1 \mathrm{~mol})$ とベンゼン $50 \mathrm{ml}$ の混合溶液 を，トランス 1,2 -シクロプロパンジカルボン酸クロリド, $167 \mathrm{~g}$ $(1 \mathrm{~mol})$ とベンゼン $200 \mathrm{ml}$ の混合溶液中に $0 \sim 4^{\circ} \mathrm{C}$ で滴下し, さらに，1時間かきまぜを続けたのち，18 $\mathrm{g}(1 \mathrm{~mol})$ の水を加え た。次にベンゼン層を分留して, $71 \mathrm{~g}(49.2 \%)$ のモノェステル を得た。 bp $114 \sim 116^{\circ} \mathrm{C} / 4 \mathrm{mmHg}, \mathrm{mp} 40 \sim 42^{\circ} \mathrm{C}$, 分析值 (理論 值, $\mathrm{C}_{6} \mathrm{H}_{8} \mathrm{O}_{4}$ として) C 49.61\%(50.00\%); H 6.19\% (5.60\%)。 このモノェステルを $30^{\circ} \mathrm{C}$ で 2 倍量の塩化チオニルで処理する と, 対応する酸塩化物 ( V b ) がほぼ定量的に得られた。bp $103^{\circ} \mathrm{C} /$ $27 \mathrm{mmHg}$ 。（Vb）から（II）への還元は，ソジウムボロハイド ライドを用いて，シス異性体の場合と同様に行なった。最高収率 $63 \%$, bp $82 \sim 84^{\circ} \mathrm{C} / 4 \mathrm{mmHg}$, 分析值 (理論值, $\mathrm{C}_{6} \mathrm{H}_{10} \mathrm{O}_{3}$ として)

C 55.66\% (55.31\%); H 8.01\% (7.75\%)。 ポリウレタン (IXp) の合成

(VI) $6.5 \mathrm{~g}(0.05 \mathrm{~mol})$ を $80 \%$ ヒドラジンヒドラート $3.8 \mathrm{~g}$ $(0.06 \mathrm{~mol})$ と共に $80^{\circ} \mathrm{C}$ で， 1 時間加熱して，4.4g(67.5\%)
のビドラジド (VII) を得た。 $\mathrm{mp} 111 \sim 113^{\circ} \mathrm{C}$, 分析值 (理論值, $\mathrm{C}_{5} \mathrm{H}_{10} \mathrm{O}_{2} \mathrm{~N}_{2}$ として) C $46.36 \%$ (46.14\%); H 7.95\% (7.75\%);

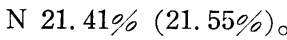

次に（VIII） $1.1 \mathrm{~g}(0.0085 \mathrm{~mol})$ をシス異性体（III）の場合と同 様にして，西硝酸ナトリウムで処理し，生成した酸アジドをアニ ソールで抽出し，無水硫酸マグネシリムで乾燥したのち， $150^{\circ} \mathrm{C}$ で 5 時間加熱した。この溶液から，アニソールを留去し，残分を $N$ ーメチルピロリドンに溶解し，それをアセトン中に加えてポリ ウレタン（Xp）を当い粉末として得た。収量 $0.29 \mathrm{~g}$ (30.30\%)。 $\mathrm{mp} 175 \sim 185^{\circ} \mathrm{C}, \eta_{\mathrm{inh}}=0.23\left(32^{\circ} \mathrm{C}, 0.5 \mathrm{~g} / 100 \mathrm{ml}\right.$, 溶媒, $N, N$ ジメルホルムアミド)。分析值（理墖值， $\left(\mathrm{C}_{5} \mathrm{H}_{7} \mathrm{O}_{2} \mathrm{~N}\right)_{\mathrm{n}}$ として) C $52.84 \%$ (53.09\%); H $6.46 \%$ (6.24\%) ; N $12.10 \%$ (12.38 $\%$

\section{ポリエステル（VIIp）の合成}

重合法は, エステル交撸に上る, 再合の常法に従って行なっ た。触媒量は $2 \mathrm{~g}(0.015 \mathrm{~mol})$ の（VI）に対して $1.3 \mathrm{mg}$ の酢 酸カルシウムと $0.3 \mathrm{mg}$ の三酸化アンチモンである。反応は封管 中 $200^{\circ} \mathrm{C}$ で 110 時間，次いで開管して, $12 \mathrm{mmHg}, 150^{\circ} \mathrm{C}$ で 20 時間， $150^{\circ} \mathrm{C}, 3 \mathrm{mmHg}, 7$ 時間，最後に $200^{\circ} \mathrm{C}, 3 \mathrm{mmHg}$ で 30 時間加熱した。 $\eta_{\mathrm{inh}}=0.14\left(32^{\circ} \mathrm{C}, 0.5 \mathrm{~g} / 100 \mathrm{ml}\right.$, 溶媒, $N, N$ ジメチルホルムアミド), 分析值 (理論值, $\left(\mathrm{C}_{5} \mathrm{H}_{6} \mathrm{O}_{2}\right)_{\mathrm{n}}$ として) $\mathrm{C}$ $61.43 \%(61.21 \%)$; H $6.27 \%$ (6.17\%)。 